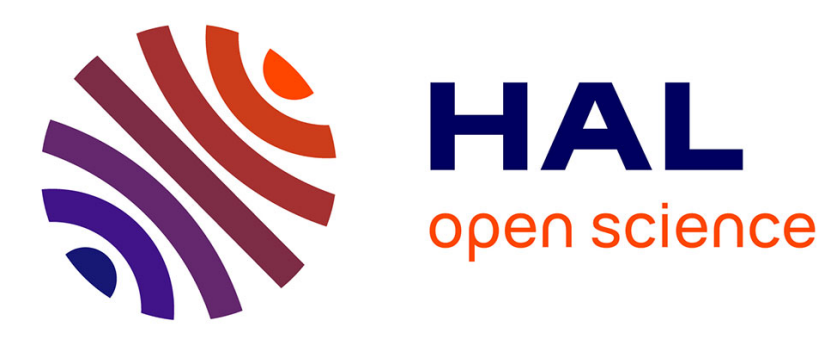

\title{
Crossing the Boundaries in Information Science: Perspectives on Interdisciplinarity.
}

Tatjana Aparac-Jelušic, Fidelia Ibekwe-Sanjuan, Isto Huvila, Lai Ma, Virginia Ortiz-Repiso Jimenez, Julian Warner

\section{- To cite this version:}

Tatjana Aparac-Jelušic, Fidelia Ibekwe-Sanjuan, Isto Huvila, Lai Ma, Virginia Ortiz-Repiso Jimenez, et al.. Crossing the Boundaries in Information Science: Perspectives on Interdisciplinarity.. 76th ASIS\&T Annual Meeting., Nov 2013, Montreal, Canada. pp.1-4. hal-00881841

\section{HAL Id: hal-00881841 https://hal.science/hal-00881841}

Submitted on 9 Nov 2013

HAL is a multi-disciplinary open access archive for the deposit and dissemination of scientific research documents, whether they are published or not. The documents may come from teaching and research institutions in France or abroad, or from public or private research centers.
L'archive ouverte pluridisciplinaire HAL, est destinée au dépôt et à la diffusion de documents scientifiques de niveau recherche, publiés ou non, émanant des établissements d'enseignement et de recherche français ou étrangers, des laboratoires publics ou privés. 


\section{Crossing the Boundaries in Information Science: Perspectives on Interdisciplinarity}

\author{
Tatjana Aparac-Jelušić \\ University of Zadar \\ taparac@unizd.hr
}

\author{
Lai Ma \\ University College Dublin \\ lai.ma@ucd.ie \\ [corresponding author]
}

\author{
Fidelia Ibekwe-SanJuan \\ University of Lyon 3 \\ fidelia.ibekwe-sanjuan@univ- \\ lyon3.fr
}

\author{
Virginia Ortiz-Repiso Jimenez \\ Universidad Carlos III de Madrid \\ virginia@bib.uc3m.es
}

\author{
Isto Huvila \\ Åbo Akademi University \\ Isto.huvilia@,abo.fi \\ Julian Warner
Queen's University of Belfast
j.warner@qub.ac.uk
}

\section{KEYWORDS}

Theoretical foundations, interdisciplinarity, research agenda -information science, documentation.

\begin{abstract}
Information science has often been recognized as an interdisciplinary field. The marriage between librarianship/documentation and computer science was a natural development in the United States in the post-War period (Farkas-Conn, 1991; Hahn \& Barlow, 2012), while the development of information science in Europe has largely stayed close to the humanities and the social sciences, in particular, in relation to communication and media (Ibekwe-SanJuan, et al., 2010). For many years, the interdisciplinary nature of information science has been applauded; until recently, we are warned that interdisciplinarinity may be harmful to the identity of the field. Buckland (2012) states that the claim of being "interdisciplinary" is to choose a position of weakness because "in times of economic crisis political power tends to reside in well-established disciplines." Cronin (2012) comments that "the field's sense of identity, arguably fragile at the best of times, is likely to be further weakened" for its "epistemic promiscuity."

This international panel aims to discuss the theoretical boundaries of information science in relation to disciplinarity and to the identity of information science with a special reference to the premises, promises and implications of diverging historical and contemporary
\end{abstract}

This is the space reserved for copyright notices.

ASIST 2013, November 1-6, 2013, Montreal, Quebec, Canada

Copyright notice continues right here. traditions in different European countries and in the US. Is information science gaining strength by being more interdisciplinary or is "the basic problem for LIS seems at the moment to be a lack of sufficiently strong centripetal forces keeping the field together" as Hjørland (forthcoming) fears. Does IS risk disintegration or dilution if it is being pulled more by centrifugal forces towards neighbouring disciplines rather than by centripetal forces? Is the main problem of IS "epistemological promiscuity"? This panel will discuss how IS in their different geographical or cultural zones has grappled with these issues which are in essence issues of boundaries. In particular, we will discuss the following questions:

- How information science is affiliated with other disciplines (e.g. natural sciences, social sciences, or interdisciplinary fields) in different regions, countries and institutions represented by the panelists?

- How is interdisciplinarity perceived in the panelists' institution/country?

- What are the main theories, if any, that inform research in information science and the formation of research areas in different regions, countries and institutions?

- Why and how the identity and disciplinarity of information science matter in the context of the work of information science researchers and practitioners?

\section{THE PANEL}

After a brief introduction by the moderator, Fidelia IbekweSanJuan, on the different viewpoints that have been expressed on interdisciplinarity and how it might be achieved or how it might be affecting disciplinary structures (Ibekwe-SanJuan 2012), each panelist will address the 
above listed questions. Following the presentations there will be a 30 minute discussion: What are the theoretical and methodological boundaries in
information science?

\section{EXTENDED ABSTRACTS}

Tatjana Aparac-Jelušić will focus on theoretical boundaries of information science(s) in relation to disciplinary tradition of archival, library and museology studies as part of historical and contemporary traditions in South-East Europe. In her attempt to explain how information science is affiliated with other disciplines she will shed light on unifying principles of information and communication disciplines and fields of practices that could provide new framework for disciplinary theory. She will discuss interdisciplinarity in particular as a desired strength that might lead towards new paradigm of IS in digital society, theory of information organization and retrieval in digital environment as a base for future research and how these attempts might influence the identity and disciplinarity of new paradigm of information science related to the work of information science researchers and practitioners.

Isto Huvilia discusses the disciplinarity of IS from a Nordic perspective, by briefly describing the evolution of the field during the second half of the 20th century and highlighting the current disciplinary trends in IS in Scandinavia, Finland and Iceland. The Nordic IS has been traditionally seen as closely related to the Anglo-American tradition of information science research, but a closer look at the current situation shows that the disciplinary, both practical and theoretical affiliations are more complex than that. The analysis of Huvila shows how the current disciplinary affiliations of IS in different Nordic departments has evolved in an intricate interplay of scholarly, personal, social and societal tendencies, priorities and decisions, and how the contemporary research policy climate may have a significant impact in the development, identity and interdisciplinarity of a discipline and/or subject.

Lai Ma discusses the development of information studies in Ireland and the effects and affects of interdisciplinarity. Information studies in Ireland began as a library school, with the launch of the "Diploma in Library Training". The first Examination candidates were conferred at the University College Dublin's alma mater building near St Stephen's Green in Dublin on May 4th, 1929 (Brown, 2009). "Information studies" was introduced in the late 1970s and the introduction was not only a change of a label, but also signified changes in curricula, research initiatives, and funding opportunities. Collaborative and interdisciplinary research is increasingly encouraged by academic institutions and funding agencies. Interdisciplinarity seems to be a necessity in an era of "the vanishing 'I'", but would it also entail the merging of epistemic cultures that leads to the fading of boundaries of theories, concepts, and methods?

Virginia Ortiz-Repiso discusses the institutional changes and research trends in library and information science in Spain. In the beginning LIS in Spain was associated with humanistic faculties only, but now it is increasingly frequent to find it linked with the fields of Computer Science or Social Sciences. The research trends have also changed: While the topics used to be linked either with practical matters concerning library operations or be purely theoretical, today bibliometrics and scientometrics are clearly positioned, and so are the topics related to information architecture, semantic web, linked data and digital environments and the work teams are increasingly interdisciplinary. The trend in publication patterns has also changed: if papers were previously published primarily in Spanish and in Spanish magazines, now they are more often published in international journals and in English. According to Schlögl (2013), Spain comes in second in Europe as far as the number of LIS publications is concerned. But in Spain not everything is wine and roses for LIS. The number of students is decreasing, possibly due to the current economic crisis, government policies and an endemic lack of social recognition of our profession.

Julian Warner discusses information science from the perspective of the United Kingdom. Two conceptions of information science can be discerned, one which is primarily a subdiscipline of library and information science and another which takes a broader perspective on information phenomena. The influence of the organisation of research in the United Kingdom on the sustainability of small and interdisciplinary areas is discussed. The broader conception of information science is endorsed. It can, and should, include the established concerns of information science in its narrower sense. The danger of the seductions of over generality (White and McCain, 1998, p. 353) can be avoided by a rigorous focus on specific empirical issues. Finally, it is suggested that adoption of a broader conception of information science may be crucial to the survival of the discipline.

\section{PANELISTS}

\section{Tatjana Aparac-Jelušić}

Professor at the Department of Information Sciences, University of Zadar and Dean of the $\mathrm{PhD}$ program Knowledge Society and the Information Transfer. Professor Aparac-Jelušić has received Kukuljević's Award (Croatian highest award in LIS field) and ASIST/Thompson/ISI Outstanding Teacher of Information Science 2006. Her main research interests are theory of IS, convergence of disciplines and digitization of written heritage. She is currently the co-director of the LIDA conference.

\section{Fidelia Ibekwe-SanJuan}


Associate Professor in the Information and Communication Department at the University of Lyon - France. Professor Ibekwe-SanJuan is interested in a wide spectrum of topics spanning empirical and applied (IR, topic mapping and text mining) and theoretical issues pertaining to the epistemological foundations of IS in the anglophone and francophone worlds, the history of information science, history of science, user studies and impact of technological innovation on society. She has recently published a book on the history and theories of Information Science (La Science de l'Information. Origines, Theories et paradigmes, Hermès-Lavoisier, published in French in 2012).

\section{Isto Huvila}

Senior Lecturer in information and knowledge management at the School of Business and Economics, Åbo Akademi University in Turku, Finland, and Associate Professor at the Department of ALM, Uppsala University in Sweden. His primary areas of research include information work and information management, theories and foundations of information research, documentation, and social and participatory information practices. Huvila has given numerous invited talks and published over 50 refereed articles, most in high ranking international journals and conference proceedings including JASIST, JDOC, ISIC, ASIST-AM and CoLIS.

\section{Lai Ma}

Lecturer at the School of Information and Library Studies at University College Dublin and the incoming Chair of the Special Interest Group for History and Foundations of Information Science (SIG/HFIS). She is interested in foundational concepts, methodology, and standards in information science and has published these subjects in the Journal of the American Society for Information Science and Technology.

\section{Virginia Ortiz-Repiso Jimenez}

Associate Professor at Carlos III University of Madrid and Head of the Department of Library and Information Science. Professor Jimenez has been involved in Bologna Process at a national and international level. Her main interests, as a researcher and professor, are in areas related to managing technology in information units, and searching and retrieving information in electronic environments. Currently, she is the chairman of Spanish Departments Network of Library and Information Science (RUID).

Julian Warner is a faculty member at the Queen's University Management School, Northern Ireland, United Kingdom, where he teaches courses in the human aspects of modern information and communication technologies and in information policy. He has been a visiting scholar at the Universities of California at Berkeley, Illinois, and Edinburgh. He has research interests in creativity for copyright, information retrieval, in the connections between writing and computing, and in understandings of information technology. His most recent publications are Creativity for Feist, Journal of the American Society for Information Science and Technology, 2013, and, Human Information Retrieval (Cambridge, MA: MIT Press, 2010).

\section{SPONSORSHIPS}

This panel session is sponsored by the ASIS\&T Special Interest Group for History and Foundations of Information Science (SIG/HFIS) and ASIS\&T European Chapter.

\section{REFERENCES}

Buckland, M. (2012). What kind of science can information science be? Journal of the American Society for Information Science and Technology, 63(1), 1-7

Brown, B. T. (2009). Towards 100 years of LIS education and research at UCD. Aslib Proceedings: New Information Perspectives, 61(3), 282-301.

Cronin, B. (2012). The waxing and waning of a field: Reflections on information studies education. Information Research, 17(3).

Farkas-Conn, I. S. (1990). From documentation to information science: The beginnings and early development of the American Documentation InstituteAmerican Society for Information Science. New York: Greenwood.

Hahn, T. B., \& Barlow, D. L. (2012). The fortuitous confluence of the National Science Foundation, the American Society for Information Science \& Technology, and Information Science. Proceedings of the ASIS\&T 2012 Pre-Conference on the History of ASIS\&T and Information Science and Technology Worldwide, Baltimore, MD, October 27, 2012.

Hjørland, B. (forthcoming). Information science and its core concepts: Levels of disagreement. In F. IbekweSanJuan \& T. Dousa (Eds.), Theories of Information Communication \& Knowledge. A multidisciplinary approach.. Dordrecht: Springer.

Ibekwe-SanJuan, F., Ingwersen, P., Aparac- Jelušić, T., \& Schloegl, C. (2010). Information science in Europe. Proceedings of the 73th Annual Meeting of the American Society for Information Science and Technology, Pittsburgh, PA, October 22-27, 2010.

Schlögl, C. (2013). International visibility of European and in particular German-language publications in library and information science. Proceedings des 13. Internationalen Symposiums für Informationswissenchaft (ISI 2013). Postdam, 19. Bis 22. März 2013, 50-62.

White, H.D. and McCain, K.W. (1998). Visualizing a discipline: an author co-citation analysis of information science, 1972-1995. Journal of the American Society for Information Science, 49(4), 327-355. 